\title{
ENHANCING EFFICIENT PAYMENTS AND REMITTANCES SYSTEMS THROUGH EFFECTIVE AML/CFT COMPLIANCE
}

\author{
BY
}

\author{
DR. ABDULLAHI SHEHU
}

\begin{abstract}
Financial remittances facilitate human capital formation by improving access to education and health; an increase in investments and reduction in poverty especially for recipient households. Also, remittances serve as a critical source of foreign exchange for the national accounts and they promote macroeconomic stability. It has been estimated that remittances are now more than double the size of net official flows, and are second to Foreign Direct Investment (FDI) as source of external finance for developing countries. To derive maximum benefits and forestall the misuse of remittance channels for the purposes of concealing the proceeds of crime, it is crucial to adopt and enforce effective anti-money laundering and counter financing of terrorism measures of acceptable international standards. This paper examines the importance of payments and foreign remittances systems; and drawing lessons from the mutual evaluation of countries in West Africa, concludes that effective and efficient compliance can only be achieved with a strong commitment of the industry to enforce self regulation. Other measures to enhance the efficiency of the payments and remittances systems are also recommended.
\end{abstract}

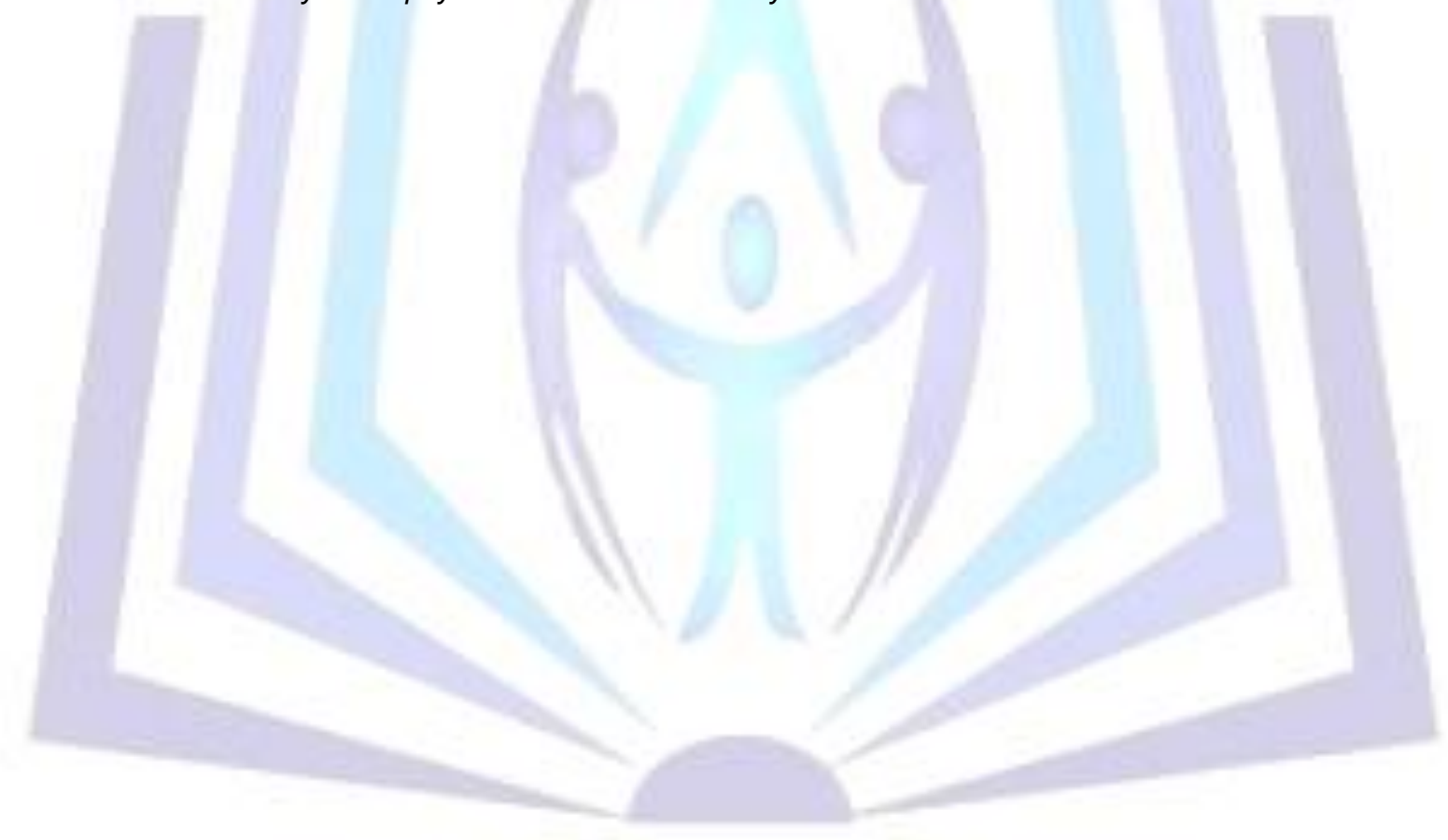

\section{Council for Innovative Research}

Peer Review Research Publishing System

\section{Journal: Journal of Social Sciences Research}

Vol. 5, No. 1

Jssreditor.cir@gmail.com

www.jssronline.com

679 | P a g e

Septem ber 13, 2014 


\section{Introduction}

Remittances have become a major source of external development finance and, contribute in many cases to economic development. They have been a remarkably stable source of income relative to other public capital flows, and are seen to be compensatory in nature, rising when the recipient country's economy suffers a downturn. In other words, remittances play stabilising roles at the aggregate levels in recipient countries as a result of their countercyclical nature (Chami, et al; 2010). As altruistic and unrequited transfers, remittances have the potential to cushion the effects of cyclical variation in income (Ratha, 2003). Thus, remittances are cross-border payments and are a nontrivial fraction of Gross Domestic Product (GDP). In particular, remittances facilitate human capital formation by improving access to education and health, and they lead to an increase in investments and reduction in poverty, especially for recipient households ${ }^{1}$. Also, remittances serve as a critical source of foreign exchange for the national accounts and they promote macroeconomic stability. It has been estimated that remittances are now more than double the size of net official flows, and are second to Foreign Direct Investment (FDI) as source of external finance for developing countries (Ratha, 2003). Other benefits of remittances noted by Ratha (2004) include:

(a) Remittances can lead to currency appreciation and affect traditional exports, because as remittances tend to be relatively stable and persistent, the appropriate policy response however is not to sterilize the inflows, but to learn to live with them.

(b) Remittances can help obtain and improve credit ratings of countries.

(c) Financial institutions receiving remittance can securitize future remittances for raising capital from international capital markets.

(d) Diaspora bonds can potentially raise significant amounts of development financing.

Payments and remittance systems can be used for legal and illegal payments. Because there have been more concerns about the suspected illegal remittances, several efforts have been made to quantify such payments. The World Bank (2013) estimated officially recorded remittance flows to developing countries to have reached about US $\$ 402$ billion in 2012 growing by $5.3 \%$ compared to the previous year and remittance are estimated to further grow by $8.8 \%$ annually during $2013-2015$ to reach about $\$ 515$ billion in 2015 . The Global Financial Integrity (2006) estimated illicit financial flows from developing countries at $\$ 859$ billion to $\$ 1.06$ trillion per annum. Thus, migration and remittances are being featured in the ongoing discussions on Millennium Development Goals (MDGs) and the post 2015 agenda. Let me draw from the estimates for the 15 Economic Community of West Africa States (ECOWAS) countries who have witnessed steady growth in the quantum of inward remittances, as well as implementation of the Financial Action Task Force 40 Recommendations across the globe, to illustrate that enhancing the payments and remittances systems through effective anti-money laundering and counter financing of terrorism (AML/CFT) standards implement can enhance the efficiency of the systems. Between 2003 and 2010, the total inward remittance to the region was US $\$ 70.03$ billion with Nigeria and Senegal receiving $72.6 \%$ and $11 \%$ respectively (see figure 1 below). Using the geometric mean, the annual growth rate for the period was $25.49 \%$, and with an estimated population of $295 \mathrm{~m}$ people in the region in 2009, the average annual receipt was US $\$ 237.48$ per person. On country by country basis, annual per head receipt is highest in Cape Verde, followed by Senegal, Nigeria, Togo, Gambia, Benin, Mali and Guinea Bissau respectively. This trend shows that, on average, less populated

\footnotetext{
${ }^{1}$ In smaller economies, significant remittance flows could assist in the establishment of small scale enterprises, thus, creating employment opportunities and reducing poverty. It also assists families to afford to train children in school or acquire some skills.
} 
countries receive more inflows than the densely populated nations. It should be noted that the slowdown of remittances to ECOWAS countries in 2009 - 2010 was a worldwide phenomenon due to (a) the economic slowdown in the high-income OECD destination countries including the USA and Western Europe which account for almost twothird of remittance flow to developing countries, (b) impact of the financial crisis, (c) uncertainty about exchange rate and (d) impact of a fall in oil prices in South Asia, Middle East and North Africa and On developing countries(see table 1 below for detail breakdown and source of data). A brief discussion on the FATF Standards and their implementation in the subsequent sections of paper will explain the usefulness of the standards in promoting better payments and remittances systems.

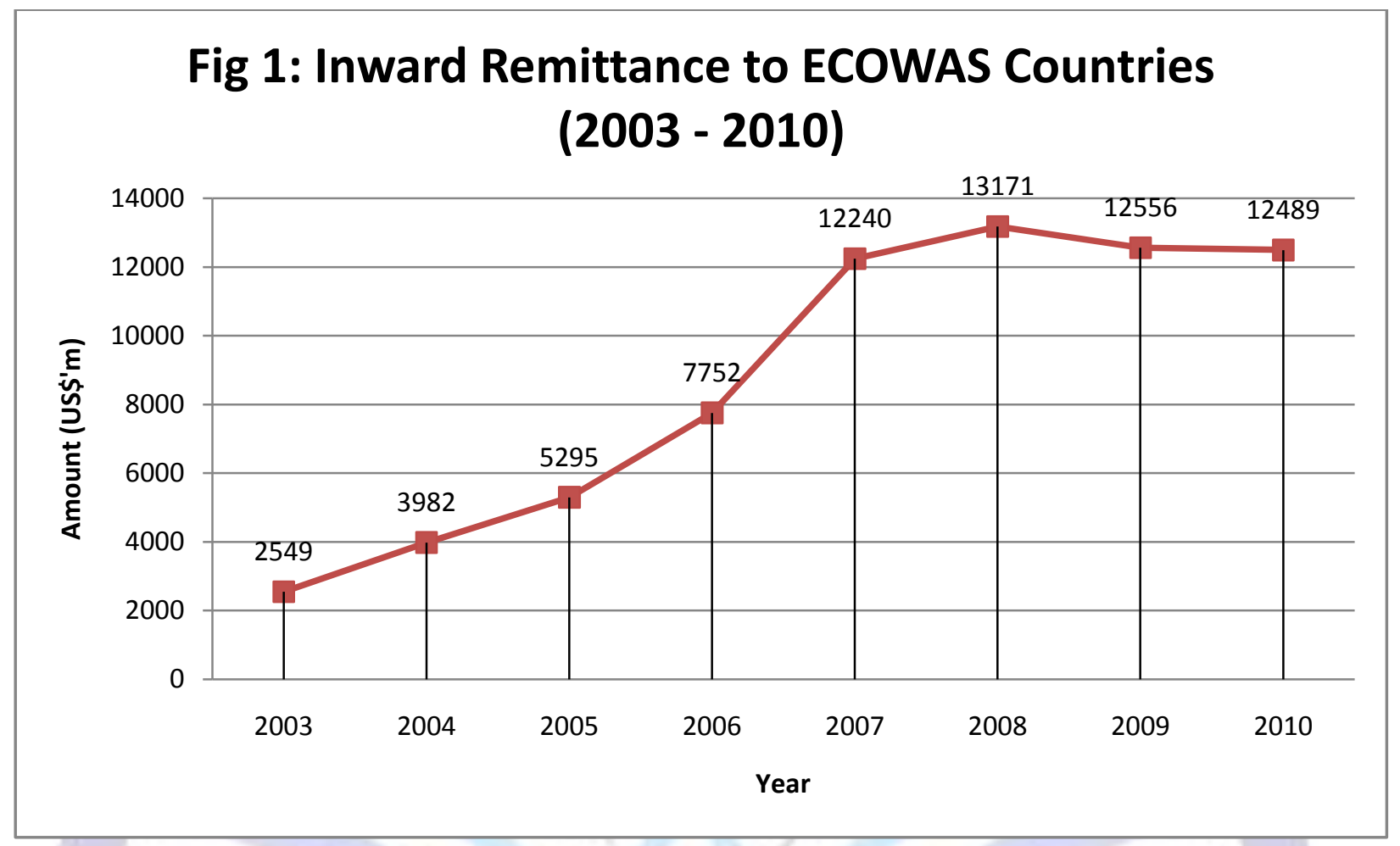

Table I: Inward Remittances for ECOWAS Countries (2003 - 2010)

\begin{tabular}{|c|c|c|c|c|c|c|c|c|c|c|c|c|c|}
\hline $\begin{array}{l}\mathbf{S} / \\
\mathbf{N}\end{array}$ & $\begin{array}{l}\text { COUNT } \\
\text { RY }\end{array}$ & $\begin{array}{c}\text { Populatio } \\
\text { n }(2009 \\
\text { est }(m))\end{array}$ & \multicolumn{8}{|c|}{ INWARD REMITTANCE FLOWS* (US\$MILLION) (2003 - 2010) } & $\begin{array}{c}\text { Total } \\
\text { (US'm) }\end{array}$ & $\%$ & $\begin{array}{c}\text { Av. } \\
\text { Annu } \\
\text { al } \\
\text { Rece } \\
\text { ipt } \\
\text { Per } \\
\text { Hea } \\
\text { d }\end{array}$ \\
\hline 1 & BENIN & 8.9 & 55.0 & 63.0 & 173.0 & 224.0 & 282.0 & 271.0 & 243.0 & 236.0 & $1,547.0$ & $\begin{array}{r}2.2 \\
\% \\
\end{array}$ & $\begin{array}{r}173 . \\
82 \\
\end{array}$ \\
\hline 3 & $\begin{array}{l}\text { CAPE } \\
\text { VERDE }\end{array}$ & 0.5 & 109.0 & 113.0 & 137.0 & 137.0 & 139.0 & 155.0 & 145.0 & 144.0 & $1,079.0$ & $\begin{array}{r}1.5 \\
\% \\
\end{array}$ & $\begin{array}{r}2158 \\
.00 \\
\end{array}$ \\
\hline 4 & COTE & & & & & & & & & & & 2.0 & 65.3 \\
\hline
\end{tabular}




\begin{tabular}{|c|c|c|c|c|c|c|c|c|c|c|c|c|c|}
\hline & $\begin{array}{l}\text { D'IVOIR } \\
\text { E }\end{array}$ & 21.1 & 143.0 & 159.0 & 163.0 & 167.0 & 185.0 & 199.0 & 185.0 & 177.0 & $1,378.0$ & $\%$ & 1 \\
\hline 5 & $\begin{array}{l}\text { GAMBI } \\
\text { A, THE }\end{array}$ & 1.7 & 65.0 & 62.0 & 57.0 & 64.0 & 63.0 & 67.0 & 60.0 & 61.0 & 499.0 & $\begin{array}{r}0.7 \\
\% \\
\end{array}$ & $\begin{array}{r}293 . \\
53 \\
\end{array}$ \\
\hline 6 & GHANA & 23.4 & 65.0 & 82.0 & 99.0 & 105.0 & 117.0 & 126.0 & 114.0 & 119.0 & 827.0 & $\begin{array}{r}1.2 \\
\% \\
\end{array}$ & $\begin{array}{r}35.3 \\
4 \\
\end{array}$ \\
\hline 7 & $\begin{array}{l}\text { GUINE } \\
\text { A }\end{array}$ & 10.1 & 111.0 & 42.0 & - & 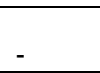 & 151.0 & 72.0 & 68.0 & 66.0 & 510.0 & $\begin{array}{r}0.7 \\
\% \\
\end{array}$ & $\begin{array}{r}50.5 \\
0 \\
\end{array}$ \\
\hline 8 & $\begin{array}{l}\text { GUINE } \\
\text { A } \\
\text { BISSAU }\end{array}$ & 1.6 & 23.0 & 28.0 & 28.0 & 28.0 & 29.0 & 30.0 & 28.0 & 27.0 & 221.0 & $\begin{array}{r}0.3 \\
\%\end{array}$ & $\begin{array}{r}138 . \\
13\end{array}$ \\
\hline 9 & $\begin{array}{l}\text { LIBERI } \\
\text { A }\end{array}$ & 4.0 & - & 58.0 & 32.0 & 79.0 & 62.0 & 58.0 & 54.0 & 57.0 & 400.0 & $\begin{array}{r}0.6 \\
\% \\
\end{array}$ & $\begin{array}{r}100 . \\
00 \\
\end{array}$ \\
\hline $\begin{array}{l}1 \\
0\end{array}$ & MALI & 13.0 & 154.0 & 155.0 & 177.0 & 212.0 & 344.0 & 431.0 & 405.0 & - & $1,878.0$ & $\begin{array}{r}2.7 \\
\% \\
\end{array}$ & $\begin{array}{r}144 . \\
46 \\
\end{array}$ \\
\hline $\begin{array}{l}1 \\
1 \\
\end{array}$ & NIGER & 15.3 & 25.0 & 60.0 & 66.0 & 78.0 & 79.0 & 79.0 & 75.0 & 70.0 & 532.0 & $\begin{array}{r}0.8 \\
\% \\
\end{array}$ & $\begin{array}{r}34.7 \\
7 \\
\end{array}$ \\
\hline $\begin{array}{l}1 \\
2 \\
\end{array}$ & $\begin{array}{l}\text { NIGERI } \\
\text { A }\end{array}$ & 154.7 & $\begin{array}{l}1,063 . \\
0\end{array}$ & $2,273.0$ & $\begin{array}{l}3,329 . \\
0\end{array}$ & $\begin{array}{l}5,435 . \\
0\end{array}$ & $9,221.0$ & $9,980.0$ & $9,585.0$ & $9,975.0$ & $50,861.0$ & $\begin{array}{r}72.6 \\
\% \\
\end{array}$ & $\begin{array}{r}328 . \\
77 \\
\end{array}$ \\
\hline $\begin{array}{l}1 \\
3 \\
\end{array}$ & $\begin{array}{l}\text { SENEG } \\
\mathrm{AL}\end{array}$ & 12.5 & 511.0 & 633.0 & 789.0 & 925.0 & $1,192.0$ & $1,288.0$ & $1,191.0$ & $1,164.0$ & $7,693.0$ & $\begin{array}{r}11.0 \\
\% \\
\end{array}$ & $\begin{array}{r}615 . \\
44 \\
\end{array}$ \\
\hline $\begin{array}{l}1 \\
4 \\
\end{array}$ & $\begin{array}{l}\text { SIERR } \\
\text { A } \\
\text { LEONE }\end{array}$ & 5.7 & 26.0 & 25.0 & 2.0 & 16.0 & 42.0 & 28.0 & 47.0 & 48.0 & 234.0 & $\begin{array}{r}0.3 \\
\% \\
\end{array}$ & $\begin{array}{r}41.0 \\
5 \\
\end{array}$ \\
\hline $\begin{array}{l}1 \\
5 \\
\end{array}$ & TOGO & 6.6 & 149.0 & 179.0 & 193.0 & 232.0 & 284.0 & 337.0 & 307.0 & 302.0 & $1,983.0$ & $\begin{array}{r}2.8 \\
\% \\
\end{array}$ & $\begin{array}{r}300 . \\
45 \\
\end{array}$ \\
\hline & Total & 294.9 & $\begin{array}{l}2,549 . \\
0\end{array}$ & $3,982.0$ & $\begin{array}{l}5,295 . \\
0\end{array}$ & $\begin{array}{l}7,752 . \\
0\end{array}$ & $\begin{array}{l}12,240 . \\
0\end{array}$ & $\begin{array}{l}13,171 . \\
0\end{array}$ & $\begin{array}{l}12,556 . \\
0\end{array}$ & $\begin{array}{l}12,489 . \\
0\end{array}$ & $70,034.0$ & $\begin{array}{r}100 . \\
0 \%\end{array}$ & \\
\hline \multicolumn{11}{|c|}{${ }^{\star}$ consists of workers' remittances, compensation of employees and migrants' transfers } & & & \\
\hline & $\begin{array}{l}\text { Ann } \\
\text { Rat } \\
\end{array}$ & Growth & - & $56.2 \%$ & $33.0 \%$ & $46.4 \%$ & $57.9 \%$ & $7.6 \%$ & $-4.7 \%$ & $-0.5 \%$ & & & \\
\hline
\end{tabular}

Source: World Bank - Migration and Remittances FactBook 2011 ( $2^{\text {nd }}$ Edition)

Despite the high level of receipts, the remittances market in West Africa has been inundated by several challenges, including: lack of transparency in market operations; lack of competitive market conditions; lack or absence of appropriate regulation; and weak payment infrastructure. These challenges arose due to adverse effects of exclusivity clauses; overly restrictive government policies; inconvertibility of the currencies in the region; low savvy of the banked citizenry and lack of robust infrastructure. These challenges therefore provided leeway for increasing dependence on informal remittance systems and also opportunities for abuse of the payments and remittances systems by criminals and for criminal activities. In view of the importance of remittances, it has become expedient to address the issue of robustness of financial infrastructure supporting remittance; and to design and implement balancing policies on anti-money laundering and combating the financing of terrorism (AML/CFT) requirements and those facilitating remittances. Before dwelling on that, we shall briefly examine the vulnerability of the systems in order to put the issues in proper perspectives.

\section{Vulnerability of the Remittances and Payments Systems to Money Laundering and Terrorist Financing}

Remittances represent the 'human face' of globalization. The flows of both human and financial capital have profound implications for economies of remitting and receiving countries. The past decades witnessed tremendous growth in remittances such that at the macro level, they have assumed gargantuan proportion in development finance. At the micro level, remittances offer direct opportunity to improve access to financial services, with greater pro-poor and rural outreach by linking remittances to products such as savings and loans. 
Remittance and its payment models especially the wire transfers are channels which could be misused to launder the proceeds of crime. Wire transfer is the most sought after financial instrument by criminals. A wire transfer is the highest valued instrument, and criminals constantly look for ways to infiltrate or establish wire remittance outlets to convert cash into the prized wire transfer payment orders. Wire transfer allows criminals to transfer funds at low risk and with speed of movement, hence facilitating the second and third stages of the money laundering - layering and integration (Forbes, 2007).

The vulnerability of remittances and wire transfers has been further entrenched by technological changes and new business models that bring together the convergence of telecommunication and financial services. It has been established that money or value transfer systems have been discovered to be vulnerable to misuse for money laundering and terrorist financing activities (FATF, 2009). The FATF typologies that revealed this has been corroborated by a number of researchers. For example, in November 2001, barely two months after the terrorist attacks on the world Trade Centre and the Pentagon in the United States of America, the US Treasury Department shut down the largest Somali remittance transfer company, Al-Barakat, because the company was linked to terrorist organisations such as al-Qaeda (Dean, et al; 2006 and Vleck, 2006).

Also, in their study, Elu and Price (2011) ascertained that in line with rational choice-theoretic approach, the expected number of terrorism incidence in sub-Saharan Africa (SSA) increases with respect to remittance flows. The authors estimated that approximately one terrorism incident is financed in SSA for remittance inflows that range between 25 50 million dollars. Thus, to the extent that remittances finance terrorism, they have the potentials to inhibit economic growth as terrorism can constrain important drivers of growth, such as investment and consumption expenditures. Also, Shelley (2005), Sanderson (2004), Prefontaine and Dondurand (2004), and Makarendo (2003) opine that money launderers and financiers of terrorism deploy remittances through wire transfers to move money through multiple jurisdictions. Other experts, including Masciandaro (2005 and 2004), Shehu (2005), Schneider (2004) and Savona (2002) agree that criminals use a variety of methods to move money especially the techniques known as "Star Burst" (the deposit of dirty money into a bank account with standing instructions to wire in small and random fragments to hundreds of other bank accounts around the world). However, tracking down such money is an uphill task as it could take several years to pursue and investigate bank accounts in multiple jurisdictions (Napoleoni, 2005).

Inadequate regulation and weak rule of law provide ideal conditions for the blending of money laundering and terrorist financing activities and the misuse of the remittance systems. In other words, lack of control of the financial system has made it easy for criminals to transmit and receive money with relative anonymity as evidenced by investigation into the 9/11 attacks (Verdugo-Yepes, 2008 and Vleck, 2006). Criminals use both the formal and informal financial systems that they can manipulate with ease (Giraldo and Trinkunas, 2007). Just as the formal banking system has been used by criminals to transfer, conceal or launder their ill-gotten gains, the informal financial structure has on occasions been used by criminals to perpetrate their illegal activities (Shehu, 2003). This is why the main thrust of this paper is to enhance the efficiency of the payments and remittances systems through effective AML/CFT in order to prevent and protect them from misuse for the purposes of laundering the proceeds of crime and to provide platforms for easy financial transactions and promoting economic development. 
Recognising the vulnerability of remittances to abuses, the G-8 countries in June 2004 at Sea Island, agreed to take collective actions that would facilitate a safe and transparent remittance systems. The G- 8 agreed at the summit to "promote coherence and coordination of international organisations that are working to enhance remittances services, including protection from abuse by criminals and heighten the development impact of receipts in developing countries". Also, the Summit sought to address the issue of appropriate statistical definition of remittances for the purpose of Balance of Payments compilations. The Summit noted that aattracting remittance flows into formal channels can strengthen financial systems in developing countries and reduce the risk that remittances will be diverted for illicit purposes. G8 countries will work with the World Bank, IMF, and other bodies to improve data on remittance flows and to develop standards for data collection in both sending and receiving countries. They also agreed that the G8 countries will also lead an international effort to help reduce the cost of sending remittances. The developmental impact of these flows may be fostered by increasing financial options for the recipients of these flows. From the foregoing, it is imperative that regulation and corporate governance are critical to the efficient functioning of the remittances market. As part of the regulatory framework, I therefore present an overview of the AML/CFT framework relating to the remittance systems.

\section{Overview of the Global AML/CFT Standards and Requirements for Payments and Remittances Systems}

The element of life - long accountability in the public sector, which does not exist in the private sector, is an important factor that should keep the operators and managers of the system, fearfully, in check. Yet this system often seems out of control or incapable of controlling the excesses and/or greed of the managers of the system. Recent embarrassing revelations of frauds, embezzlements, outright theft and other financial crimes perpetrated by public officers give the impression of a system full of weaknesses and loopholes waiting to be abused and taken advantage of by, not only, those who are paid to protect its integrity and see it perform as designed, but also those who use the systems for their private businesses. The accentuation of this ugly development would ultimately undermine the very reason why such systems were created and encourage criminality to flourish.

The interest in establishing a transparent payment system arose due to the financial scandals and high profile investigations of the late 80's and 90's such as the C-Chase, $\mathrm{BCCl}$ and the Kerry and Nunn Committee's Congregational investigation on money laundering (FSA, 2011). In 1995, the war on organised crime escalated to a point where international economic weapons became the right option to handle these crimes. On October 22,1995 , President Clinton of the US in his address at the $50^{\text {th }}$ Anniversary of the United Nations called for international cooperation to address the threat posed by international money laundering, drug trafficking and terrorist financing and terrorism, noting that it has "moved beyond the ability of a single nation to control alone".

In 2007, the Bank for International Settlements (BIS) and the World Bank (WB) developed the General Principles for International Remittance Services. These Principles were designed to assist countries to improve the market for remittance transfers by serving as a guide and not to be prescriptive. Policymakers are expected to use these principles as an instrument to improve the regulatory framework of the remittance industry, foster competition, enhance transparency, and strengthen consumer protection in their remittance markets. Hence, the Principles are to facilitate the achievement of public policy objectives of having in place a safe and efficient international remittance services. The General Principles identified competition, transparency, accessibility and soundness as the bases for an efficient remittance market. The Principles revolve around five key goals of transparency and consumer protection; 
payment system infrastructure; legal and regulatory environment; market structure and competition; and governance and risk management.

In line with the BIS/WB General Principles, international AML/CFT Standards have been conceived to address the problem of global abuse of the financial systems, including the payments and remittances systems for the purpose of money laundering and terrorist financing. In particular, the FATF 40 Recommendations on Money Laundering and Terrorist Financing remain the most comprehensive multi-dimensional and multi-sectoral approach in the global crusade against these scourges and permit collaborations among countries.

The FATF 40 Recommendations set out a comprehensive and consistent framework of measures which countries should implement in order to combat money laundering and terrorist financing, as well as the financing of proliferation of weapons of mass destruction. Countries have diverse legal, administrative and operational frameworks and different financial systems, and so cannot all take identical measures to counter these threats. The Recommendations, therefore, set an international standard, which countries should implement through measures adapted to their

particular circumstances. The FATF Recommendations set out the essential measures that countries should have in place to:

- identify the risks, and develop policies and domestic coordination;

- $\quad$ pursue money laundering, terrorist financing and the financing of proliferation;

- $\quad$ apply preventive measures for the financial sector and other designated sectors;

- $\quad$ establish powers and responsibilities for the competent authorities (e.g., investigative, law enforcement and supervisory authorities) and other institutional measures;

- $\quad$ enhance the transparency and availability of beneficial ownership information of legal persons and arrangements; and

- facilitate international cooperation.

The original FATF Forty Recommendations were drawn up in 1990 as an initiative to combat the misuse of financial systems by persons laundering drug money. In 1996 the Recommendations were revised for the first time to reflect evolving money laundering trends and techniques, and to broaden their scope well beyond drug-money laundering. In October 2001 the FATF expanded its mandate to deal with the issue of the funding of terrorist acts and terrorist organisations, and took the important step of creating the Eight (later expanded to Nine) Special Recommendations on Terrorist Financing. The FATF Recommendations were revised a second time in 2003, and these, together with the Special Recommendations, have been endorsed by over 180 countries, and are universally recognised as the international standard for anti-money laundering and countering the financing of terrorism (AML/CFT) (FATF, 2012).

Following the conclusion of the third round of mutual evaluations of its members, the FATF has reviewed and updated the FATF Recommendations, in close co-operation with the FATF-Style Regional Bodies (FSRBs) and the observer organisations, including the International Monetary Fund, the World Bank and the United Nations. The revisions address new and emerging threats, clarify and strengthen many of the existing obligations, while maintaining the necessary stability 
and rigour in the Recommendations. The FATF Standards have also been revised to strengthen the requirements for higher risk situations, and to allow countries to take a more focused approach in areas where high risks remain or implementation could be enhanced.

Combating terrorist financing is a very significant challenge. This is also obvious with regard to the possible misuse of payments and remittances systems for terrorist financing. An effective AML/CFT system, in general, is important for addressing terrorist financing, and most measures previously focused on terrorist financing are now integrated throughout the Recommendations, therefore obviating the need for the Special Recommendations.

The FATF Standards comprise the Recommendations themselves and their Interpretive Notes,

together with the applicable definitions in the Glossary. The measures set out in the FATF Standards should be implemented by all members of the FATF and the FSRBs, and their implementation is assessed rigorously through Mutual Evaluation processes, and through the assessment processes of the International Monetary Fund and the World Bank - on the basis of the FATF's common assessment methodology.

I have provided this lengthy background to the FATF Recommendations in order to enable us gain a better understanding of the specific standards and requirements pertaining to the payments and remittances systems and the challenges likely to be encountered in effectively implementing the standards. It should be reiterated that the FATF Requirements are not designed to impose rigid standards or to mandate a single operating process that would negatively affect the payments systems. As with all laws and/or regulations, there is the tendency that those for remittances are either poorly designed or implemented by countries with unintended side effects, that they are disproportionate to the problem they were designed to solve or are continued to be applied even when they are no longer relevant. For this obvious reason, and to continually ensure that stakeholders are on track, a summary overview of the FATF AML/CFT requirements for the remittances and payments systems is thus, discussed below.

The two basic Revised FATF Recommendations on Payments and Remittances systems are Recommendations 14 and 16 (previously SR VI and SR VII). Under R. 14, countries are required to put in place consistent AML/CFT measures designed to address the vulnerability of the money or value transfer (MVT) systems by ensuring the transparency of the payment flows. In particular, countries are to take special note of alternative remittance system that operates outside the purview of regulatory framework for the formal financial sector. The Recommendation requires the existence of effective monitoring and compliance systems, and application of appropriate sanctions. Under this Recommendation, countries are required to designate a competent authority to regulate the system through adequate licensing and/or registrations.

The focus of .R 16 is the prevention of money launderers and terrorist financiers from abusing the wire transfer system. Countries are expected to facilitate effective application of this Recommendation by ensuring timely availability of comprehensive information on the originator of the wire transfer. This information is to assist law enforcement agencies in detecting, investigating and prosecuting money laundering and terrorist financing cases, and also for tracing the assets of criminals so as to deny them the usage of their illicit wealth. Furthermore, the information is expected to assist the beneficiary financial institutions or MVT companies to establish the identity of their customers thereby facilitating reportage of suspicious transactions to the Financial Intelligence Units (FIUs). Thus, the requirements of $R$. 16 include verification of information, maintenance of information for a specific duration, and adoption of effective risk-based procedure in identifying wire transfers that lack complete originator details. 
The application of Recommendations 14 and 16 should be in conjunction with other related Recommendations, especially those on preventive measures (R. $9-$ R. 34) to be taken by financial institutions and designated nonfinancial businesses and professionals (DNFBPs). Therefore, remittance service providers (RSPs) and other DNFBPs are required to undertake customer due diligence to ascertain the true identity of a customer - be it a politically exposed person or otherwise. In this vain, the Recommendations require reporting entities to maintain records for at least ten years and to report any suspicious transaction to law enforcement to facilitate investigation and prosecution of money laundering and terrorist financing cases that would eventually culminate in conviction. This relationship is demonstrated in the figure below.

\section{RELATIONSHIP BETWEEN R. 14 AND R. 16 AND OTHER RECOMMENDATIONS}

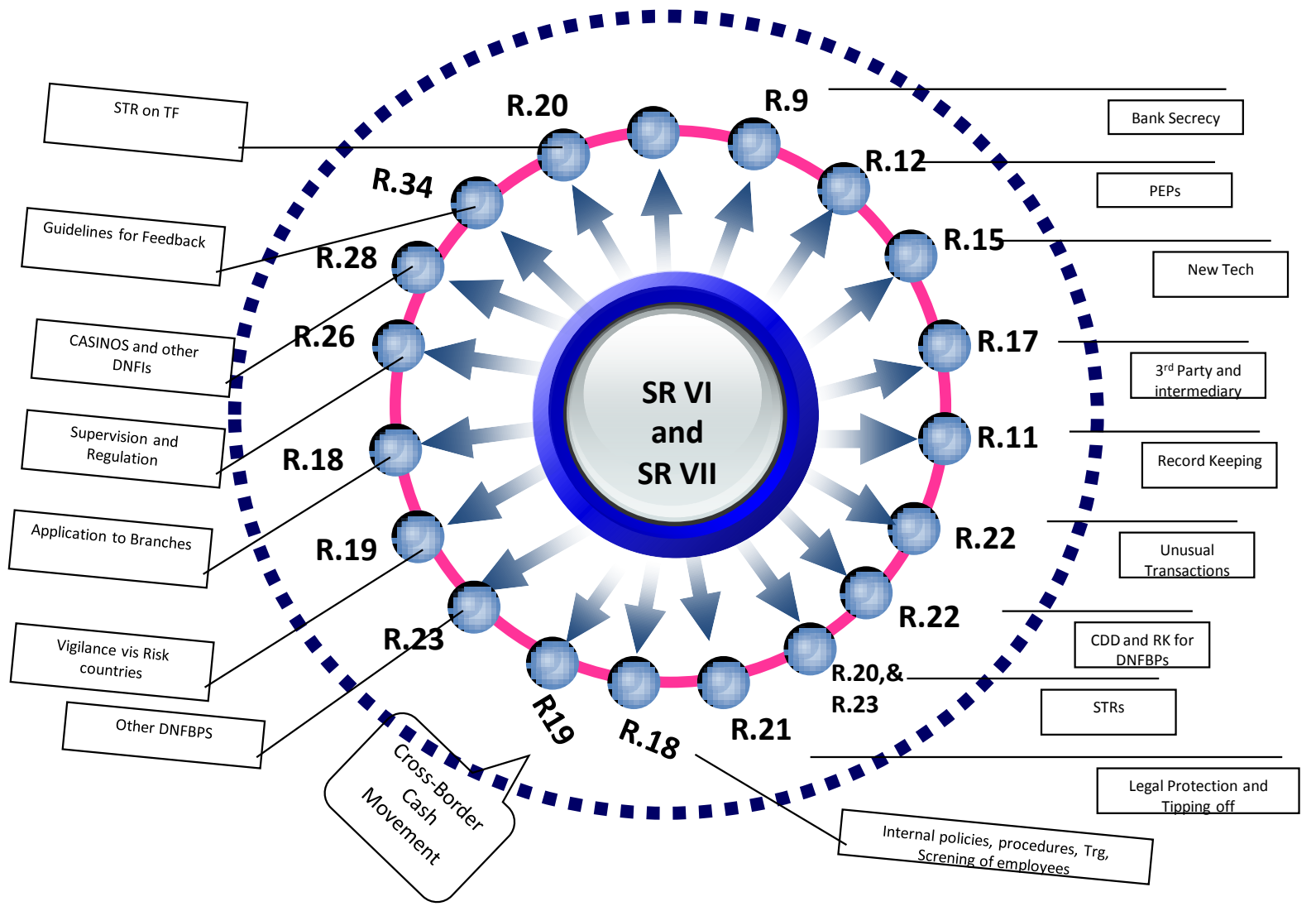

It important to note that the application of both the General Principles for Remittances and the FATF Recommendations is to ensure that AML/CFT framework facilitate service delivery with adequate controls in place. Remittance Service Providers (RSPs) are therefore required to put in place a robust AML/CFT program to minimise the risk of their facilities being misused for money laundering and terrorist financing activities. Thus, the AML/CFT framework should enhance the capacity of RSPs to deliver services and products in cost efficient manner that promotes transparency and good corporate governance in operations. 
Drawing from the compliance level of countries in West Africa under the Inter-Governmental Action against Money Laundering in west Africa (GIABA)'s first round of mutual evaluation conducted between 2007 and 2013, it is possible to imagine that the low compliance levels their mutual evaluation reports show that in general, the countries are struggling with the implementation of the FATF Standards, in particular, the following three components of the AML/CFT framework: preventive measures to be taken by Fls and DNFBPs in the old recommendations which were used for the evaluations (Recs 4 - 25); Institutional and other measures necessary in the system (Recs 26 - 34); and the 9 Special Recommendations on TF (SR I - IX). The poor compliance level on the preventive measures is a pointer to the level of vulnerability of the financial systems to money laundering and other related crimes. This poor performance is of serious concern as this component constitutes about 55 percent of the entire framework. Thus, weaknesses in this area portend a major source of concern. This, therefore, calls for a holistic action by both the reporting entities (Fls and DNFBPs) and the supervisors/regulators to improve compliance programmes. These results further corroborate the features of low capacity countries with regard to the implementation of AML/CFT regime.

The low level of compliance with Customer Due Diligence (CDD-R.5) requirements shows that FIs and DNFBPs are yet to adopt comprehensive measures in identifying and verifying the identity of their customers, including that of legal persons, legal arrangements and beneficial ownerships. In the region, most of the Financial Intelligence Units (FIUs) are operating sub-optimally, hence their capacity to collect, analyse and disseminate suspicious transaction reports (STRs) that facilitate investigation and prosecution is impaired. As indicated by the low rating on Recommendation 23, the supervisory/regulatory frameworks for both the Fls and DNFBPs are weak.

Also, the non-criminalization of all predicate offences, including terrorism and terrorist financing negates the principles of nullum crimen sine lege in law. For any act to be considered a crime there must be legal foundation providing for its existence. Thus, in view of the phenomenological transnational dimensions of ML and TF, it is important that all ECOWAS countries as recommended in their MERs should criminalize the full range of predicate offences. It should be noted that criminals and criminal organisations take advantage of the asymmetries emanating from the existence of different legal systems.

The low level of compliance to the FATF Standards is reminiscence of the peculiarities and challenges of low capacity countries. This therefore calls for enhanced regulatory and enforcement measures. The deployment of both repressive and preventive measures is sine qua non. Criminals tend to perpetrate their illegal activities due to existence of attractive conditions (Shehu, 2003; and Masciandro et al, 2007). Accordingly, money launderers tend to prefer jurisdictions with lax AML/CFT regimes. Until recently, most AML/CFT regimes, especially in developing countries pay less attention to the potential for abuse of gatekeepers, including the remittance channels. Against this backdrop, I will now briefly discuss some of the compliance with relation to payments and remittances systems.

\section{Compliance Challenges in relation to Payments and Remittances Systems}

Overall, a cursory review of the Mutual Evaluation reports (MERs) of most countries, especially under the first rounds of evaluations would reveal that while some of the FATF Standards are not implemented at all, certain Recommendations are rarely applied due to their undertones. In particular, the application of the old R.6 (now R.12) has been fraught with lack of clear jurisdictional definition and treatment of Politically Exposed Persons (PEPs). Although PEPs are not common users of remittances system, "a priori" identification of PEPs is rare even though they 
are "obvious" or "known" to the general population even in conducting due diligence with in financial institutions, especially less developed financial systems. Their "identification" is usually "posterior", through arrests/indictment/prosecution/trial/conviction (of which there are relatively few officially recorded cases) and/or exposure by the mass-media. Still, the primary survey data suggest that PEPs are made up mostly of high-level government officials, political office-holders, police/law-enforcement and judicial officials, as well as high level private personnel (GIABA, 2010).

Another compliance problem has to do with the poor knowledge of reporting obligation by accountable institutions, which has encouraged the practice of submission of 'defensive' Suspicious Transactions Reports (STRs). This is a practice where in some countries, reporting entities dole out a large number of STRs to the Financial Intelligence Unit (FIU) that do not add value to investigation and prosecution of ML/TF cases. Apart from the cost of compliance, the issue of liability and how to manage the impact of reporting on public relations and corporate image is another challenge for reporting entities. One of the greatest fears of financial institutions and DNFBPs is that disclosure could lead to a customer run, which may affect the viability of their businesses in a competitive free market economy. Financial institutions do fear a possible retribution by suspected customers when disclosures are made (Shehu, 2003).

All these risk indicators generate some dilemmas of 'constructive trusteeship' because from whatever angle we look at 'suspicion', it remains a subjective concept. According to Levi \& Naylor (2000: 8), since the demand for criminal goods and services is 'inelastic', their value increases as successful law enforcement increases.

The core problem in many jurisdictions is that the methods of conducting Know Your Customer (KYC) identification rely on information provided by the customer. As identity theft has become a feature of fraud, it might be misleading for payments and remittances systems to rely on information provided by a customer. Professional money launderers should not find it difficult to produce fake or forged documents representing their identities to surmount the obstacle of identification. In view of the flaws in KYC procedure, it would be better to develop a system of monitoring certain clients or types of transaction on the basis of risk perception rather than devoting time and resources to every individual customer for full identification. At the same time, if this is not done, the tendency is to overlook potential launderers. This is a serious dilemma that needs more thought. The challenge is to place emphasis on customer profile rather than identification details.

Other challenges and constraints in effectively enforcing AML/CFT risk based approach in the payments and remittances systems, just as in the formal financial institutions, includelow capacity (both human and institutional) to implement AML/CFT measures; weak regulatory and legal frameworks for effective implementation of $\mathrm{AML} / \mathrm{CFT}$ regimes; poor coordination among competent authorities; informal and cash-based nature of the economies; and poor data management in terms of documentation and data retention.

\section{The Way Forward - Recommendations}

The benefits of implementing AML/CFT regimes are enormous. As stated by President George W. Bush (2001), the aim of AML/CFT measures is to "starve the money launderers and terrorists of funding, turn them against each other, rout them out of their safe hiding places, and bring them to justice". This statement calls for collective action and concerted efforts by all stakeholders. No amount of legislation and regulation can effectively enhance the efficiency of payments and remittances systems than self regulation, that is, the commitment of the industry to police itself. The 
best legislation or regulations may be left to the discretional implementation of industry practitioners who may turn a 'blind eye' to attempts to conceal illegal funds through the remittances systems.

One of the major policy issues identified in this study is the rationale for a reporting threshold imposed on banks and other financial institutions. This may vary from one jurisdiction to another. In this case, we need to distinguish between a money movement facility (in a financial institution mainly) and money laundering. As Gold \& Levi (1994) argue, the fact that one places money in a bank account does not necessarily means that one has laundered money. Funds transfer is entirely a different thing from money laundering. Since the aim and objective of banking is to make profit, we need more convincing data, perhaps more than mere suspicion to distinguish between a bank's legitimate interests in providing money movement as a legitimate endeavour and money laundering as a 'professional' offence. How do we regulate the movement of cash concealed in suitcases? For example, would it be proper for any country to enforce a random search on all incoming and outgoing visitors in order to discover the movement of cash? This will certainly infringe upon individual liberty and may have implications for legitimate commercial activities.

Overall requirements for an effective AML/CFT regime should include at the minimum, especially in less developed economies the following:

* Enhancing political commitment to the fight against ML and FT through appropriate policy design. Obviously, a strong political commitment leads to multiple results, including effective compliance, investigation and prosecution of culpable cases of breach

* Designing AML/CFT regimes to peculiarities of each jurisdiction. As contained in the revised FATF Recommendation 1, assessing risk and applying a risk-based approach in AML/CFT, and coordinating efforts is necessary.

* Institutionalization of effective corporate governance framework and industry compliance culture;

* Building the capacity of the judiciary, enforcement and supervisory regimes to facilitate investigation, prosecution and conviction of $\mathrm{ML} / \mathrm{TF}$ cases;

* Establishing comprehensive policy value chain that permits

$\checkmark$ Good understanding of domestic and external risks (national risk assessment)

$\checkmark$ Supervisory intensity that promotes depth of examination and deployment of outcomes of supervisory actions;

* Providing adequate financial resources to competent authorities especially the FIUs;

* Adopting risk-based approach to AML/CFT compliance functions by both the regulators and operators (Fls and DNFBPs). Integrating the informal financial system with formal financial system to promote financial inclusion. Financial inclusion and effective AML/CFT regime can and should be complementary, and pursue mutual benefits within national policy objectives. Countries should tap the flexibility embedded in the international AML/CFT standards to enable them to craft effective and appropriate controls. The challenge anyway, is on how to determine the right mix for the two i.e., what level of protection is suitable for a particular financial environment?

With respect to the remittances and payments sectors, the following actions will facilitate paradigm shift AML/CFT and enhance the efficiency of the systems:

- Immediate revision of the benefits of exclusivity to the economy and prohibiting RSPs from having contracts with exclusivity;

- Reduction of remittance transfer costs; 
- Encouraging the use of formal remittance systems;

- Improving data collection practices, and compliance practices at Fls and DNFBPs;

- Developing more productive remittance paradigms with positive effect on economy;

- Developing industry AML/CFT compliance culture that promotes process improvement;

- Enhancing regional cooperation that would facilitate harmonization of regulations;

- Improving regulatory framework to meet international standards and to ensure that these regulations facilitate liberalization of the remittance market;

- Improving enforcement of regulations to promote competition;

- Providing clear guidance to operators and address the issue on the role of agents;

- Ensuring the application of AML/CFT requirement to all players in a consistent while keeping in mind riskbased approach especially for inward flows that do not contain required information;

- Improving transparency of remittance market and consumer protection by ensuring full disclosure of all fees to both senders and recipients; and

\section{Conclusion}

The importance of remittances cannot be over-emphasized as they have been ascertained to be the second largest source of development finance. The growth of the remittance market has been dramatic. However, the efficiency of the market can be inhibited by lack of transparency, poor regulation and bad corporate governance which enhance the possibility of the system to misuse by criminals, especially money launderers and terrorist financiers. Thus, it is imperative to have in place adequate supervisory regime anchored on robust AML/CFT framework that promotes optimal functioning of the remittances and payments systems. Implementers of the AML/CFT framework should deploy risk-based approach to ensure judicious use of available limited resources. It should be noted that financial inclusion and effective AML/CFT regime are complementary. Thus, the need to develop well balanced and proportionate AML/CFT regulatory frameworks, which reconcile financial inclusion's objectives with the AML/CFT requirements, is apparent. Meeting these goals requires that any national AML/CFT regime be tailored to the domestic circumstances ${ }^{2}$.

Evidence abound on the vulnerability of many countries to money laundering as demonstrated by reported and investigated cases, while cases of terrorist financing are emerging and manifesting in several countries. Most of these cases, especially from developing countries are obviously intimately linked to corruption. Therefore, especial attention must be given to corruption as a factor in law enforcement and regulation of systems meant to enhance payments and remittances. The FATF Recommendations provide the minimum standards for countries to regulate their systems according to their national legal systems, but consistent with acceptable international standards.

Efforts to strengthen AML/CFT standards must therefore take into account specific domestic circumstances and legal systems. The practical reasons why some customers use the informal transfer systems rather than the formal ones should be properly understood to guide in the development of appropriate regulatory framework for the informal payment systems. But most importantly, a risk-based approach in regulating the payments remittances systems must

\footnotetext{
${ }^{2}$ That is why it is strongly recommended that countries should first undertake a risk assessment in their AML/CFT systems before embarking on reforms. This will also assist in the formulation of appropriate policies and development of a National AML/CFT Strategy with succinct procedures for implementation over time.
} 
address factors that lead to the inefficiency of the systems, including high transaction costs, long delays in effecting remittances, exchange control measures and other overly bureaucratic procedures (Zagari, 2007).

\section{References}

Bush, G. W. (2001), "President Freezes Terrorists Assets” speech by President George W. Bush, September 24, 2001, www.whitehouse.gov/news/releases/2001/09/\#

Chami, R., D. Hakura, and P. Montiel. (2010): "Do Worker Remittance Reduce Output Volatility in Developing Countries?" DRAFT October 6, 2011.

Deans, F., L. Lonnqvist, and K. Sen (2206): "Remittances and Migration: Some Policy Considerations for NGOs', INTRAC Policy Briefing No.8, International NGO Training and Research Centre, Oxford, UK.

Elu, J.U and G. N. Price (2011): “Do Remittances Finance Terrorism in Sub-Saharan Africa?” Paper Presented at the Centre for the Study of African Economies (CSAE) Conference on Economic Development in Africa, March 20-22, 2011, St. Catherine's College, Oxford University, Oxford, Uk.

FATF (2009) “Typologies Report on Alternative Remittance Systems", Paris, France. www.fatfgafi.org/typologies

FATF (2012): "International Standards on Combating Money Laundering and the Financing of Terrorism and Proliferation - The FATF Recommendations", Paris, France.

FSA (2011): "Banks' management of high money laundering risk situations", Financial Services Authority (FSA) Report, June 2011.

Forbes, J. (2007), "Effects of Cell phones on Anti-Money Laundering/Combating Financial Terrorism

(AML/CFT) through Wire Remittance Operations", Working Paper, Asian Development Bank, March.

GIABA (2010) "Corruption-Money Laundering Nexus: An Analysis of Risks and Control

Measures in West Africa".

Giraldo, J.K. and H.A. Trinkunas (2007): "Terrorism Financing and State Responses: A Comparative Pperspective. Stanford, Calif., Stanford University Press.

Global Financial Integrity (2006) “Illicit Financial Flows from Africa: Hidden resource for Development”.

Levi, Michael and T. Naylor (2000) "Organized Crime, the Organization of Crime and the Organization of Business". London: Office of Science and Technology; Foresight Directorate.

Makarenko, T. (2003): A model of terrorist-criminal relations”, Jane's Intelligence Review.

Masciandaro, D., E. Takats, and B. Unger (Eds) (2007), Black Finance: The Economics of Laundering, Edward Elgar, Cheltenham.

Masciandaro, D. (2005): "Financial Supervisory Unification and Financial Intelligence Units." Laundering Control, 8(4).

(2004): "Global Financial Crime: Terrorism, Money Maundering and Aldershot, Hans, England; Burlington, VT, Ashgate.

Napoleoni, L. (2005): "Terror Incorporated: Tracing the Dollars Behind the Terror Networks". New York, Seven Stories Press.

Prefontaine, D.C. and Y. Dandurand, (2004): "Terrorism and Organised Crime: Reflections on an Illusive Link and its Implication for Criminal Law Reform”, International Society for Criminal Law Reform, Montreal.

Ratha, D. (2003): "Workers' Remittances: an Important and Stable Source of External Development Finance”. In Global Development Finance: Striving for Stability in Development Finance. Washington DC: The World Bank 
Sanderson, T.M. (2004): "Transnational Terror and Organised Crime: Blurring the lines." Sais

Review, XXIV (1).

Savona, E. (2002): "Obstacles in Company Law to Anti-Money Laundering International Cooperation in European Union Member States", Financing Terrorism, Dordrecht; Boston, Kluwer Academic Publishers: 57 - 85.

Schneider, (2004): "The Macroeconomic Flows of Islamic Terrorism”, Global Financial C Crime”, D. Masciandaro, $97-125$

Shelly, L. (2005): "The Nexus Between Terrorism and Organised Crime", in Confronting Terrorism Financing, Lanham, MD (etc): University Press of America: 29 - 33.

Shehu, A.Y. (2010) 'Promoting Financial Sector Stability Through Effective AML/CFT', Journal of Money laundering Control, Emerald Publishing, UK,

Shehu, A.Y. (2005): "International Initiatives against Corruption and Money Laundering", Journal of Financial Crime Control, 12(3): $221-243$.

Shehu, A. Y. (2003): "Corruption and Money Laundering: A Comparative Study of Hong Kong and Nigeria", Unpublished Ph.D. Dissertation, The University of Hong Kong.

World Bank (2013) “Migration and Development Brief”. April, 19, Washington, DC, USA.

Vleck, W. (2006): "Development v. Terrorism - Migrant Remittances or Terrorist Financing?" Commonwealth Studies, University of London.

Zagari, Bruce (2007) "Problems applying traditional anti-money laundering procedures to nonfinancial transactions, "Parallel Banking Systems" and Islamic Financial Systems"; in Journal of Money Laundering Control, Volume 10, No. 2.

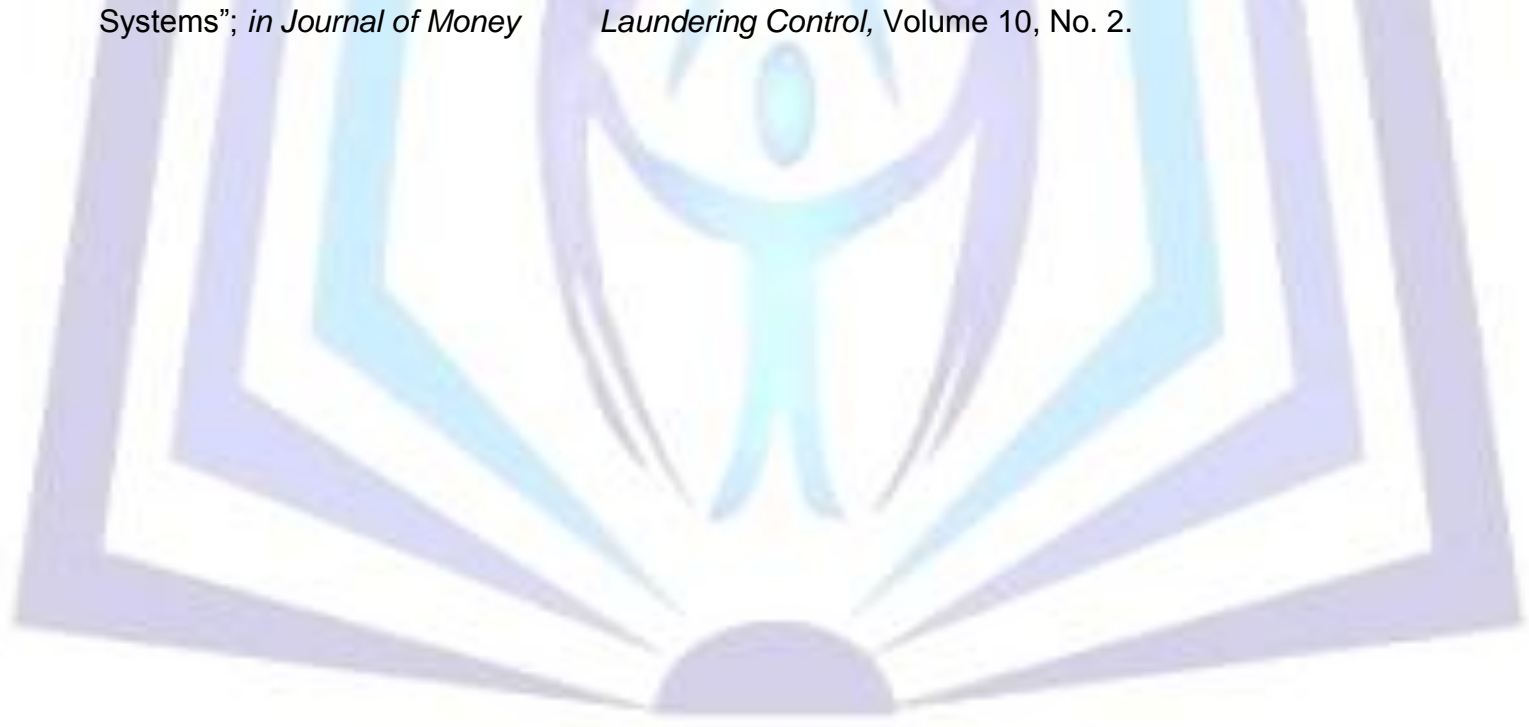

